\title{
Managing Thyself to be a Productive Manager: Insights from Bhagavad Gita
}

\author{
T. D. Weerasinghe ${ }^{1}$, S. D. Weerawardane, ${ }^{2}$ K. P. M. Priyasad ${ }^{3}$ \\ ${ }^{I}$ Senior Lecturer, Department of Human Resource Management, Faculty of Commerce and Management Studies, \\ University of Kelaniya, Sri Lanka, dananjaya@kln.ac.lk \\ ${ }^{2}$ Department of Human Resource Management, Faculty of Commerce and Management Studies, \\ University of Kelaniya, Sri Lanka, sonduruw@yahoo.com \\ ${ }^{3}$ Department of Human Resource Management, Faculty of Commerce and Management Studies, \\ University of Kelaniya, Sri Lanka, kpmalithpriyasad@gmail.com
}

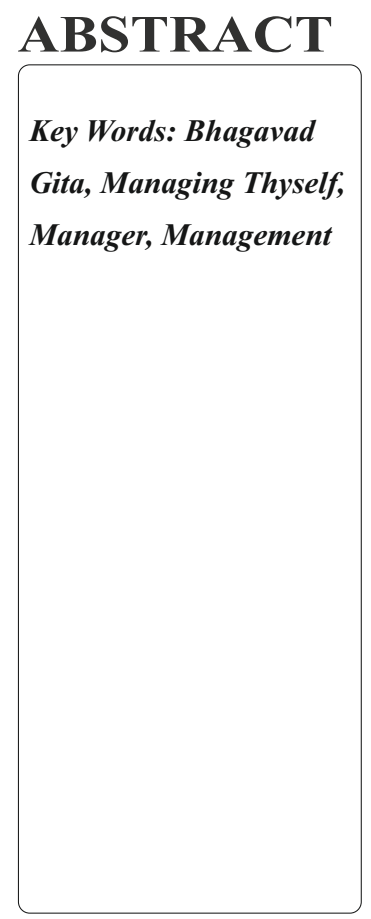

Bhagavad Gita; the divine song of the God, is not only a spiritual text, but also a guide book to develop
productive managers and people at work in the modern dynamic environment. To be a productive manager
one should manage thyself first, which is considered the foundation stone of any people management
practice. It is observed that the practitioners are fed-up with the western views and practices discussed in
the extant literature. On the other hand, eastern philosophy of managing thyself is little focused in western
literature, but gaining an increasing attention today. Hence, bridging the lacuna in the domain, the current
study attempts to review and report the insights manifested among the teachings of God Krishna, in
Bhagavad Gita, to be applied in managing thyself to be a productive manager. Anarrative literature review
of Bhagavad Gita, and key research articles on the same known to the authors was conducted. It is found in
Bhagavad Gita that, managing thyself starts from mental peace and internal consistency. For that, one
should free from the feelings of greed, envy, egotism, suspicion and anguish. Moreover, the ability to
create and follow a realistic vision for the life, and perceive the holistic view of the things better manage
thyself with the proper understanding of the causes and consequences of the practices in management
ultimately. In view of the above, this article recommends practicing mangers to incorporate the insights
revealed in Bhagavad Gita in designing and delivering employee training \& development programs,
mentoring programs, performance coaching, employee counselling and grievance handling..

\section{Introduction}

Bhagavad Gita means the song of the holy god. It teaches various paths to gain self-knowledge and the inner peace. Simply, it is a complete guide to practical life and provides all that is needed to raise the consciousness of man to the highest possible level. It includes the sermon given by God Sri Krishna to Prince Arjuna regarding the correct techniques in managing the life (Dharmaratnam, 1987, as cited in Satpathy \& Muniapan, 2008).

Lord Krishna (embodiment of wisdom) preached the Gita to Arjuna (embodiment of skill) to motivate him to perform his duty when he faced an ethical dilemma whether or not to kill his relatives and friends in the battlefield of Kurukshetra. There are 700 verses (slokas) in eighteen Chapters in the Bhagavad Gita which can address spiritual, mental, intellectual, and health problems of mankind (Rao, 2010).

Bhagavad Gita is a spiritual text which inspired many national leaders in India and around the world which they were provided the courage, moral and the inspiration to lead the struggles that they made to protect the nation (Mahadevan, 2009). Few of those leaders are Mahatma Gandhi, Albert Einstein, Sri Ramakrishna, Swami Vivekananda, Carl Jung and JawaharLal Nehru (Rao, 2010). 
Management is the art of getting things done through and with people, efficiently and effectively. Management involve planning, organizing, staffing, directing and controlling of human efforts. As per Peter Drucker, the father of modern management, management is a multipurpose organ that manage a business. He pointed out that it is the process of managing the managers, workers and the processes of organizations. Further, he emphasized that management is neither a science nor an art. It is the practice. He elaborated, as the doctors diagnoses the disease of the patient, the effective manager should be able to diagnose the situation and manage it effectively through people.

The Bhagavad Gita throughout the whole text does emphasize about many management aspects that we undergo when managing an organization. It provides many insights for effective management of an organization.

The major difference between the teachings of the Gita and the modern management is that, the modern management addresses the materialistic outcomes that is to be gained whilst the Gita concerns mainly in managing organizations paying attention to the 'roots' of the humans. It does implies that being connected with the sub conscious of people who does work will innately lead to the materialistic opportunities. Further, this can be used as a handbook for an individual to be a successful manager in an organization and also in the life.

Managers manage organizations. But, the problem is, how to be a productive manager and what lays the foundation stone to be a productive manager. It is nothing but managing thyself. Truly speaking, without managing thyself it is impossible to manage employees at work. It is observed that the management practitioners are fed-up with the western views and practices discussed in the extant literature. Moreover, eastern philosophy of managing thyself is little focused in western literature, but gaining an increasing attention today; especially during the post-pandemic of Covid-19.

\section{Objectives}

Having considered the above discussed lacuna, current review was initiated with the following objectives:

- To identify and discuss the insights for selfmanagement revealed in Bhagavad Gita.

- To identify and discuss the insights for developing leadership qualities of management practitioners revealed in Bhagavad Gita.

- To compare and contrast the insights in Bhagavad Gita with the western views \& practices, and present a balanced perspective of managing thyself.

\section{Methods}

This is a qualitative content analysis, but descriptive in nature. So, in selecting the sample for content analysis, it is not always fitting or suitable to use a random sample. Hence, a non-random sampling technique can be utilized (Saunders et al., 2012, p. 281). Given that, sometimes it is essential to consider certain materials and texts which can assist answer the research question (Saunders et al., 2012, p. 281-283). A critical sampling design is applied when a sample is necessary and crucial for the assessment of the research question (Bickman \& Rog, 1998, p. 105). Hence, in the current study we chose to use critical sampling.

Inclusion and exclusion criteria used to select the contents for the analysis were based on three keywords; managing thyself, productive managers and the Bhagavad Gita. The collected contents were analyzed using simple thematic analysis. According to Braun and Clarke (2006, p. 79) a simple thematic analysis is a process of recognizing, analyzing and outlining sequences (themes) within data. Thematic analyses attempt to discover and recognize the primary and important themes in a text at different levels, and thematic networks intention is to simplify the structuring and organizing, as well as, the illustration of these themes (Attride-Stirling, 2001, p. 387). 
As mentioned, having conducted a content analysis of relevant research articles and the Bhagavad Gita, rest of the paper summarizes and reports the insights from the preaching of Lord Krishna which are possibly useful and meaningful for practicing managers today in managing thyself to be productive managers.

\section{Critique of Literature 4.1. Self-Management}

The process of being a productive manager starts from managing thyself properly. Hence, the selfmanagement is the foundation stone that lays the base in becoming a productive manager. Bhagavad Gita mainly points out that managing thyself first is the foundation for the wellbeing of the individual, organizational and society in the long run (Chandekar, 2012).

A person should be able to control thyself in leading and managing an organization. In Gita, Lord Krishna preached that, controlling the mind, determination, giving up sense of gratification, being free from attachment and hatred, body and mind control, power of speech, free from false ego, false pride and anger as essential parts of self-management (Muniapan, 2008). Further, it was cited in Muniapan (2008), that managers who are mentally weak cannot achieve the organizational mission. The mind of the manager must be firm in driving the organizational resources towards the mission.

The studies of Mahadevan (2009) cited that in Bhagavad Gita, Lord Krishna emphasized that there is nothing as karma (state of inaction). It does underlines that when people believe that there is nothing like inaction they tend to find the means of doing the work correctly and providing them the complete degree of freedom will enable them to enjoy the work whilst achieving the fruitful outcomes.

In conclusion, every manager has to manage themselves first to manage the organization properly as managing thyself by identifying the strengths, weaknesses, opportunities and threats rather than trying to sort out the organizational objectives as a preliminary process.

Reddy (2009) cited the fact that to attain sound mental health, a manager should try to possess and maintain internal constancy, mental peace, a calm mindset and a positive poise even in adverse situations and should stay away from the feelings of greed, envy, egotism, suspicion and anguish as advocated in Bhagavad Gita.

Jeste \& Vahia (2008) stated that in Bhagavad Gita, through examples and analogies, Krishna enlightens the disillusioned Arjuna, who is consumed by prebattle regret on the prospects of warring against his evil cousins and relatives, the nature and supremacy of duty as well as several philosophical tenets for everyday living. Thus, the Bhagavad Gita is not just a concise description of Hindu philosophy, but also a compass to make meaningful decisions to manage thyself.

An uncontrolled mind is very weak and unstable; as a result not even a small obstacle coming in its way may make it lose initiative. Lord Krishna preached that:

"One who has conquered the mind, the mind
is the best of friends, but for one who has
failed to control the mind, the mind will be
the greatest enemy" (B.G. 6.6).

Managers should use their intelligence to control the mind (the driving instrument), they should not let the mind to be controlled by the senses. In the chariot of the body, the five horses represent the five senses (tongue, eyes, ears, nose and skin). The reins, the driving instrument, symbolize the mind, the driver is the intelligence, and the passenger is the self. In Bhagavad Gita, while elaborating on the issue of mind control Lord Krishna preached that:

"Mighty-armed Arjuna, it is undoubtedly that mind is very difficult to curb \& is restless, but it is possible by suitable practices of meditation \& by detachment. 
For one whose mind is unbridled, uncontrolled, self-realization is a difficult work. But, he whose mind is controlled and who strives by appropriate means is assured of success" (B.G. 6.35).

Accordingly, if one's mind is in control he/she can concentrate deeply on work. Then such a person can do wonders at work. It does emphasize how much essential the management of mind to become an example manager, as it lays the foundation for the productive management practices as well.

Today, a productive manager essentially should be a great leader. $\mathrm{He} /$ she should develop and exhibit charisma in every sphere, encourage the followers to do their own way without clashing the corporate target, and welcome the diversity.

\subsection{Developing Leadership Qualities}

Your leader is you; my leader is me. Hence, to lead others, first I should develop my leadership competencies. Indeed, developing deep qualities of leadership is essential aspect of managing thyself. It is he/she who excel leadership properly, manager the self properly (Chandekar, 2012).

Leadership is the ability to make people believe and trust the vision that is being shared, and guide them to achieve the goals and objectives. This does differentiate from the management of ensuring that the work is done properly based on processes and procedures. In an organization the top personnel have to be good managers and at the same time strong leaders to ensure that targets to be achieved. Simply, leadership is the fact which makes organizations to fall and/or rise.

The leadership qualities Lord Krishna preached were:

\section{"Whatever the master piece of work of excellence the commoners follow".}

The visionary leader will have dynamism and strength which flows from an inspired and spontaneous motivation to help others (Bhatt, 2011). Further, it does address the fact that importance of maintaining one's proper role and duties, being proactive and acting with wisdom, working for the greater good and engaging in self-sacrifice. The leader must maintain their values to achieve organizational targets.

This could be developed by acquiring a holistic vision of Bhagavad Gita. This holistic vision enables managers to think deep into human consciousness, to understand, guide, motivate, innovate and inspire their people by practicing the profound management principles himself, which set forth the eternal value system (Chandekar, 2012).

Mahadevan (2009) mentioned that developing a sense of equanimity is required to become a good leader. They should be able to manage the best and the better times both in a balanced and successful manner. The first instruction that Arjuna received from Lord Krishna is signaling the above issue was that:

"World is a full of dualities, it will blow hot and cold, and we will experience joy and happiness as well as unpleasant moments. These are the realities of life, and they will come and go. If we do not learn to endure them and go through this life as a roller coaster ride, we will never be able to exhibit leadership".

This does implies how important for a leader to develop a sense of equanimity to be a strong leader which has not been adequately discussed even in the modern western context of management.

\section{Suggestions}

Having considered the critiqued views in this paper, following suggestions could be listed for practicing managers, mentors and trainers in the domain of business management:

- Evaluate the self-awareness on selfmanagement. A simple 'personal SWOT analysis' is adequate for that purpose. 
- Update the self if needed, on selfmanagement. A simple action plan as a part of Professional Development Plan (PDP) or the overall Management Succession Plan (MSP) is possible.

- Incorporate the emphasized insights from Bhagavad Gita as appropriate into employee training and development initiatives.

- Engage in constant mindfulness training [like mediation] and 'Yoga' keeping records for the monitoring of progress.

- Be determined and train the mind to free from false ego and pride which deteriorates the own control.

- Be determined and train to develop and retain the strengths of controlling the own mind, sense of gratification, mental peace and emotional intelligence.

\section{Conclusion}

Self-management is considered the stamina to be a productive manager. Today a productive manager should also be a strong leader. In Bhagavad Gita, as Lord Krishna preached, controlling the mind, determination, sense of gratification, free from false ego and pride, maintaining internal consistency, mental peace and emotional intelligence are illustrated as essential elements of selfmanagement. It is he / she who perceive the holistic view of things, manage thyself properly in every situation to be a productive manager.

\section{References}

B Mahadevan, "Bhagwat Gita: Ideas for Modern Management," Towards a New Paradigm of Business Management - Alternative Perspectives from Ancient Indian Wisdom, Bangalore: IIM, 2009.

$B$ Satpathy and B Muniapan, "The Knowledge of 'Self' from the Bhagavad-Gita and Its Significance for Human Capital Development," Asian Social Science, Vol 4, 2008.

C Someswaranada, Business Management-the Gita Way, 2005.

D Ubha, Coparate Governance: Solution Through Indian Spritual System, 2007.

$D V$ Jeste and I V Vahia, Comparison of the Conceptualization of Wisdom in Ancient Indian Literature with Modern Views, 2008.

G Dessler, Human Resource Management (13th ed.), Boston: Pearson, 2014.

H Khan, "A Literature Review of Corporate Governance, "International Conference on E-business, Management and Economics, Vol 25, IACSIT Press, Singapore, 2011.
J Attride-Stirling, "Thematic Networks: An Analytic Tool for Qualitative Research", Qualitative Research, Vol. 1(3), 2011, 385-405.

L Bickman and D Rog, Handbook of Applied Social Research Methods (1sted.), London: Sage Publications, 1998.

MP Bhattathiri, Bhagavad Gita and Management, Kerala, 1999.

M Saunders, P Lewis and A Thornhill, Research Methods for Business Students (16thed.), Harlow: Pearson Education, 2012.

$R$ Bhatt, "Importance of Bhgavad Gita in Management," International Referred Research Journal, Vol 3, Issue 27, 2011.

$S$ B Chandekar, "Principles of Management and the Bhagavad Gita," Journal of Dharma, 2012

S Nanda, "Management Lessons From Bhagavad Gita," International Journal of Applied Research, 2016.

SMRao, Bhagavad Gita: A Translation of the Poem, Autumn Hill Books, 2010.

S M Rao, "Bhagavad Gita a key source for Management thoughts-An analysis," Acme Intellects International Journal of Research in Management, 2014.

$S$ Reddy, Business Principles from the Bhagavad Gita, New Delhi: Macmillian India Ltd, 2009.

SRobbins, and MCoulter, Management. Pearson, 2007.

$V$ Braun and V Clarke, "Using Thematic Analysis in Psychology", Qualitative Research in Psychology, Vol. 3 (2), 2006, 77-101. 